\title{
The effect of iodine from iodine-enriched alga Chlorella spp. on the pork iodine content and meat quality in finisher pigs
}

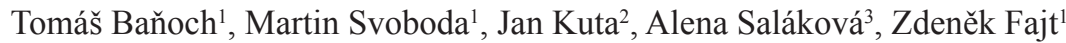 \\ ${ }^{1}$ University of Veterinary and Pharmaceutical Sciences Brno, Faculty of Veterinary Medicine, Clinic of \\ Ruminant and Swine Diseases, Brno, Czech Republic \\ ${ }^{2}$ Masaryk University Brno, Faculty of Science, Research Centre for Toxic Compounds in the Environment \\ (RECETOX), Brno, Czech Republic \\ ${ }^{3}$ University of Veterinary and Pharmaceutical Sciences Brno, Faculty of Veterinary Hygiene and Ecology, \\ Department of Meat Hygiene and Technology, Brno, Czech Republic
}

Received May 15, 2012

Accepted August 13, 2012

\begin{abstract}
The aim of the study was to evaluate the effects of iodine from iodine-enriched alga Chlorella spp. on the iodine content in pork and on meat quality traits in finisher pigs. Experimental feed mixtures were fed for a period of 3 months before slaughter. In group A $(n=12)$, the experimental feed mixture was supplemented with $2 \mathrm{mg} \mathrm{I} / \mathrm{kg}$ in the form of iodine from iodine-enriched freshwater alga Chlorella spp. The experimental feed mixture for pigs in group $\mathrm{B}(\mathrm{n}=12)$ was supplemented with $2 \mathrm{mg} \mathrm{I} / \mathrm{kg}$ in the form of KI. Group C $(\mathrm{n}=12)$ was the control group without supplementation. Compared to $\mathrm{KI}$, the use of the algal iodine resulted in significantly higher $(P<0.05)$ iodine concentrations in the thyroid, serum and muscle tissue. No differences between the two groups were found in the meat quality traits. It is concluded that iodine from iodine-enriched Chlorella spp. is retained in muscle tissue in a higher extent than inorganic KI. Nevertheless, iodine concentrations in the meat are still low to be considered as a relevant iodine source for human nutrition.
\end{abstract}

Pigs, potassium iodide, iodine enriched alga, serum, thyroid gland, muscle, iodine concentration

Iodine is an essential element. In the mammalian body, thyroid gland contains around $80 \%$ of total iodine (Herzig et al. 2007). It is required for the synthesis of thyroid hormones in humans and animals. In sows, iodine deficiency is manifested by stillbirths and delivery of weak hairless piglets. Iodine deficiency in growing-finishing pigs results in diminished growth rate. In humans it causes goiter, mental and physical retardation (cretinism, diminished growth, skeletal deformation) (Delange 1994; Kotwal et al. 2007).

There are still about 800 million people worldwide who suffer from iodine deficiency (Lauerberg 2004). In the Czech Republic, serious iodine deficiency problems in human population were reported in the 1990s and previous years (Zamrazil et al. 1996). A complex prophylaxis of iodine deficiency based on salt iodination has been established since the end of World War II. A recent epidemiological survey shows a significant improvement of thyroid function in the Czech population (Zamrazil et al. 2007).

Iodination of salt is a useful and effective strategy used in order to increase the iodine intake. However, considering that the use of iodized salt is voluntary, additional measures for iodine deficiency prophylaxis are necessary. Moreover, salt intake is one of the risk factors for the development of hypertension (Meneton et al. 2005).

An alternative strategy represents the supplementation of iodine to animal feed in order to increase its content in foods of animal origin (Flachowsky et al. 2007). Experimental studies demonstrated a remarkable transfer of iodine from the feed into the animals' milk and eggs (Kaufmann et al. 1998; Flachowsky et al. 2006). Inorganic KI is an iodine form most commonly used in animal diets. Studies evaluating the effects of feed supplementation with inorganic iodine in growing-finishing pigs revealed low transfer rates of iodine into meat (Schöne et al. 2006; Franke et al. 2008).

Address for correspondence:

MVDr. Tomáš Baňoch

Clinic of Ruminant and Swine Diseases, Faculty of Veterinary Medicine

University of Veterinary and Pharmaceutical Sciences Brno

Palackého tř. 1/3, 61242 Brno, Czech Republic 
The aim of the study was to find whether the use of organic iodine from freshwater alga Chlorella spp. would result in an improvement of pork iodine content in finisher pigs.

\section{Materials and Methods}

Experimental design

A total of 36 female pigs of Landrace $\times$ Czech Large White breed were used in the trial. The pigs started to receive experimental feed mixtures at the age of 3 months. Experimental feed mixtures were fed for a period of 3 months till slaughter. Pigs were divided into 3 equal groups. During the first 30 days, the pigs were given feed mixture A1 (30-55 kg body weight). For the rest of the trial, the pigs were given feed mixture A2. The pigs received $2.4 \mathrm{~kg}$ of feed per pig daily. The composition of diets and mineral supplements is presented in Tables 1 and 2. In group A $(\mathrm{n}=12)$, the feed was supplemented with $2 \mathrm{mg} \mathrm{I} / \mathrm{kg}$ in the form of iodine from iodine-enriched freshwater alga Chlorella spp. The alga was produced by the heterotrophic cultivation at the Microbiological Institute of the Czech Academy of Sciences in Třeboň. The enriching of alga with iodine was achieved by the addition of sodium iodide and potassium iodide into the cultivation medium. After cultivation algal biomass was obtained. One kilogram of dry biomass matter contained 2,130 mg I/ $\mathrm{kg}$. A supplement of 2 $\mathrm{mg} / \mathrm{kg}$ in the form of inorganic KI was used in the group B $(\mathrm{n}=12)$. No supplemental iodine was added to the feed mixture in group $\mathrm{C}(\mathrm{n}=12)$. Iodine was contained only in the basal diet. This group served as a negative control. The composition of the experimental feed mixtures is presented in Tables 1 and 2 . The basal diet contained $0.2 \mathrm{mg}$ of iodine.

Table 1. Percentage composition of the experimental feed mixture A1 used in fattening pigs

\begin{tabular}{lc}
\hline Ingredient & Percentage \\
\hline Wheat & 30.4 \\
Corn & 17 \\
Barley & 24 \\
Soybean pollard & 19.5 \\
Yeast Bitec Q & 2 \\
Biolac (supplemental milk mixture) & 0.8 \\
Soybean oil & 1.3 \\
Minfos MDCP20 (monodicalciumphosphate) & 0.7 \\
Limestone & 1.4 \\
NaCl & 0.4 \\
aTrace mineral and vitamin premix & 2 \\
Zeofeed (mycotoxin sorbent clinoptilolit) & 0.5 \\
\hline
\end{tabular}

Sampling

Blood from pigs was collected from v. jugularis at the beginning of the trial (90 days before slaughter), 45 days and 1 day before slaughter. Serum was collected and frozen for a subsequent analysis. The tissue samples were collected immediately after slaughter. Muscle tissue was taken from $\mathrm{m}$. biceps femoris.

Iodine analysis

The solubilization blood serum samples, muscle samples and thyroid samples were prepared according to the modified method proposed by Niedobova et al. (2005). The sample $(1 \mathrm{ml}$ or $0.5 \mathrm{~g})$ was mixed with $5 \mathrm{ml}$ of $10 \% \mathrm{w} / \mathrm{w}$ tetramethylammonium hydroxide (TMAH) in a sealable glass tube. The mixture was than heated to $90{ }^{\circ} \mathrm{C}$ for 3 h. Before the analysis, cooled blood serum samples were than diluted $10 \times$ with deionized water (Millipore Simplicity, Millipore, USA). Muscle and thyroid samples were quantitatively transferred with deionized water to $50 \mathrm{ml}$ volumetric flask.

Inductively Coupled Plasma-Mass Spectrometry (ICP-MS) (Agilent 7500ce, Agilent Technologies, Japan) was used for determination of iodine concentration in the solution. Internal standard ${ }^{127} \mathrm{Te}$ was used for diminution of matrix effects and instrumental drift. The accuracy of methodology was verified by the analysis of several certified reference materials including non fat milk powder (NIST 1549) and blood serum (Seronorm Trace Element Serum L-1). Reproducibility of the whole method for each type of matrix was tested by parallel analysis of several samples and relative standard deviation was lower than $11 \%$.

Statistical analysis

Statistical analysis of the data was performed using Statistica 8.0 for Windows (StatSoff CR). Analyzed indices were tested for normal distribution using the Kolmogorov-Smirnov test. The non-parametric Kruskal-Wallis test was used for iodine concentration and $P<0.05$ and $P<0.005$ were chosen at the level of significance. Parametric Anova test was used for pig body weights and daily weight gains. There were no differences among groups with statistical significance. 
Table 2. Percentage composition of the experimental feed mixture A2 used in fattening pigs

\begin{tabular}{lc}
\hline Ingredient & Percentage \\
\hline Wheat & 34.4 \\
Corn & 15 \\
Barley & 24.5 \\
Soybean pollard & 19.5 \\
Soybean oil & 1.2 \\
Minfos MDCP20 (monodicalciumphosphste) & 0.8 \\
Limestone & 1.3 \\
NaCl & 0.4 \\
Kalama (benzoic acid) & 0.5 \\
aTrace mineral and vitamin premix & 2 \\
Zeofeed (mycotoxin sorbent clinoptilolit) & 0.5 \\
\hline
\end{tabular}

${ }^{\mathrm{a}}$ Groups A, B: Supplied per kilogram of diet: $2.00 \mathrm{mg}$ of Iodine, $0.50 \mathrm{mg}$ of $\mathrm{Co}, 10.00 \mathrm{mg}$ of $\mathrm{Cu}, 70.00 \mathrm{mg}$ of $\mathrm{Fe}, 0.76$ $\mathrm{mg}$ of I, $30.00 \mathrm{mg}$ of Mn, $90.00 \mathrm{mg}$ of $\mathrm{Zn}, 9.00 \mathrm{mg}$ of calcium pantothenate, 6000.00 I.U. of vit. A, 990.00 I.U. of vit. D3, $35.20 \mathrm{mg}$ of vit. E, $1.20 \mathrm{mg}$ of vit. $\mathrm{K} 3,1.30 \mathrm{mg}$ of vit. B1, $4.20 \mathrm{mg}$ of vit. B2, $1.80 \mathrm{mg}$ of vit. B6, $0.03 \mathrm{mg}$ of vit. B12, $13.00 \mathrm{mg}$ of niacinamid, $0.05 \mathrm{mg}$ of biotin, $100.00 \mathrm{mg}$ of cholinchlorid. Group C: without Iodine supplementation

\section{Results}

There were no differences in iodine serum concentrations among the experimental groups in samples taken from each group 3 months before slaughter. The addition of iodine in the organic bound form (group A) resulted in significantly $(P<0.05)$ higher iodine serum concentrations compared to the control group. In group $\mathrm{B}$, iodine concentrations were significantly $(P<$ $0.05)$ higher compared to the control group in samples taken one and a half months before slaughter. However, there were no differences between groups $\mathrm{A}$ and $\mathrm{B}$. The addition of iodine in the organic bound form (group A) resulted in significantly $(P<0.05)$ higher iodine serum concentrations compared to the control group and group B in samples taken one day before slaughter. There were no differences between the control group and group B (Fig. 1).

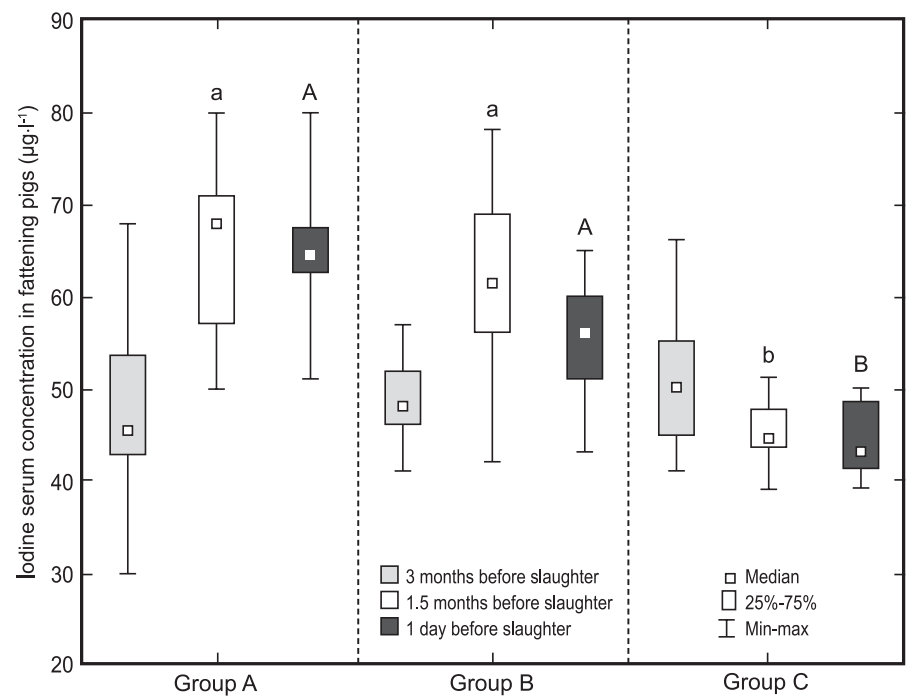

Fig. 1. Iodine serum concentrations in fattening pigs

a, b - express significant differences among groups at the level of significance $(P<0.05) 1.5$ months before slaughter. A, B - express significant $(P<0.05)$ differences among groups at the level of significance 1 day before slaughter. In group A $(\mathrm{n}=12)$ the feed was supplemented with $2 \mathrm{mg} \mathrm{I} / \mathrm{kg}$ in the form of iodine from iodine-enriched freshwater alga Chlorella spp. In group B $(\mathrm{n}=12)$ the feed was supplemented with $2 \mathrm{mg} / \mathrm{kg}$ in the form of iodine from inorganic KI (potassium iodide). In group $\mathrm{C}(\mathrm{n}=12)$ no supplemental iodine was added to the feed mixture. 


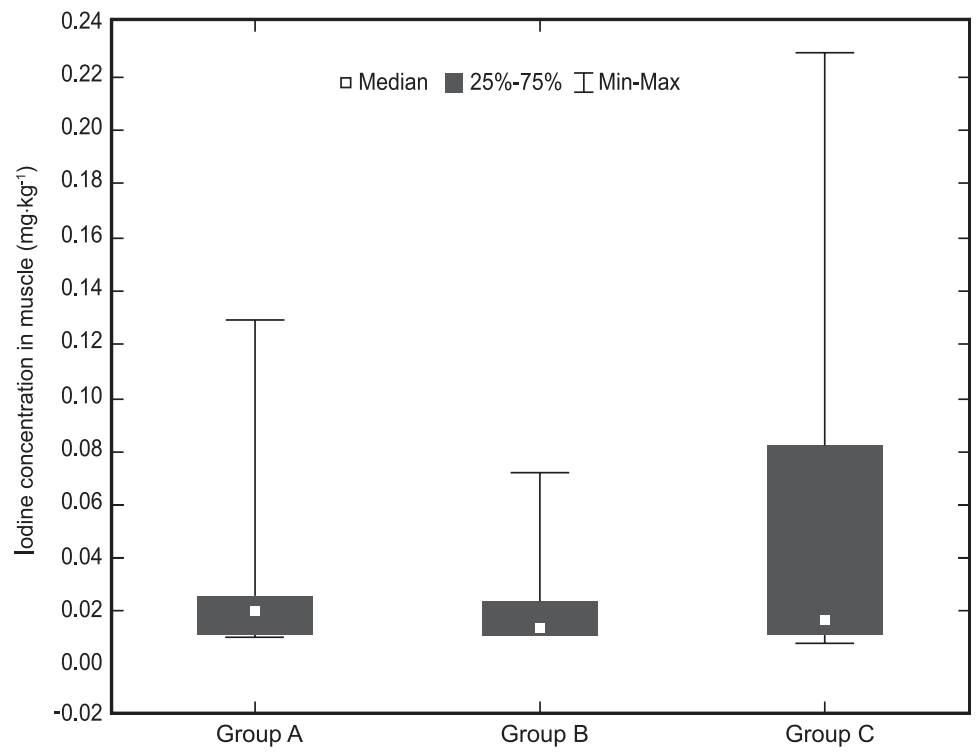

Fig. 2. Iodine muscle concentrations in fattening pigs.

In group A $(\mathrm{n}=12)$ the feed was supplemented with $2 \mathrm{mg} \mathrm{I} / \mathrm{kg}$ in the form of iodine from iodine-enriched freshwater alga Chlorella spp. In group B $(\mathrm{n}=12)$ the feed was supplemented with $2 \mathrm{mg} / \mathrm{kg}$ in the form of iodine from inorganic KI (potassium iodide). In group $\mathrm{C}(\mathrm{n}=12)$ no supplemental iodine was added to the feed mixture.

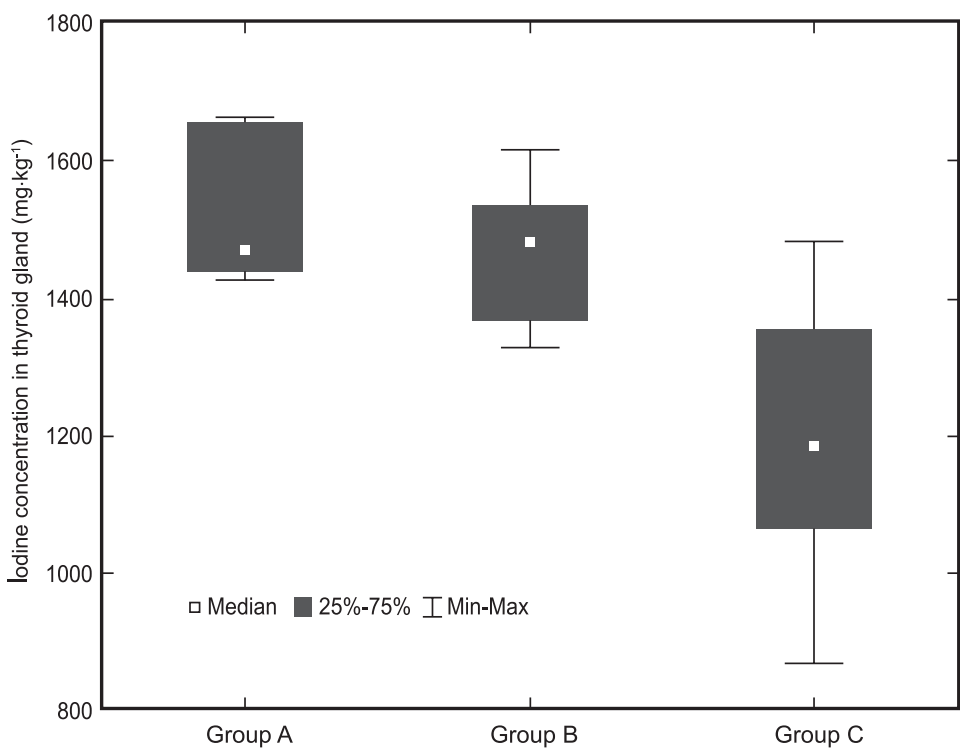

Fig. 3. Thyroid gland tissue iodine concentrations in fattening pigs

$\mathrm{a}, \mathrm{b}$ - express significant differences among groups at the level of significance $(P<0.05)$. In group A $(\mathrm{n}=12)$ the feed was supplemented with $2 \mathrm{mg} \mathrm{I} / \mathrm{kg}$ in the form of iodine from iodine-enriched freshwater alga Chlorella spp. In group B $(\mathrm{n}=12)$ the feed was supplemented with $2 \mathrm{mg} / \mathrm{kg}$ in the form of iodine from inorganic KI (potassium iodide). In group $\mathrm{C}(\mathrm{n}=12)$ no supplemental iodine was added to the feed mixture 
In our study we found no differences of iodine concentrations in muscle among the experimental groups (Fig. 2).

In the thyroid gland tissue, the addition of iodine in the organic bound form

Table 3. Performance traits (weight of fattening pigs).

\begin{tabular}{lccc}
\hline & Group A & Group B & Group C \\
& Mean \pm SD & Mean \pm SD & Mean \pm SD \\
\hline Body weight at the beginning $(\mathrm{kg})$ & $29.7 \pm 6.0$ & $27.5 \pm 4.7$ & $30.8 \pm 2.9$ \\
Body weight at slaughter $(\mathrm{kg})$ & $112.8 \pm 20.9$ & $113.5 \pm 12.4$ & $118.5 \pm 5.5$ \\
Daily weight gains $(\mathrm{g})$ & $710.0 \pm 0.2$ & $749.0 \pm 0.1$ & $776.0 \pm 0.0$ \\
\hline
\end{tabular}

Table 4. Pig muscle samples characteristics (samples from three groups).

\begin{tabular}{|c|c|c|c|c|c|c|c|}
\hline & & \multicolumn{2}{|c|}{ Group A } & \multicolumn{2}{|c|}{ Group B } & \multicolumn{2}{|c|}{ Group C } \\
\hline & & Median & $25^{\text {th }} / 75^{\text {th }}(\%)$ & Median & $25^{\text {th }} / 75^{\text {th }}(\%)$ & Median & $25^{\text {th }} / 75^{\text {th }}(\%)$ \\
\hline \multicolumn{2}{|c|}{ Hot weight $(\mathrm{kg})$} & 89.6 & $80.3 / 95.0$ & 95.7 & $90.1 / 98.2$ & 93.4 & $88.3 / 98.6$ \\
\hline \multicolumn{2}{|c|}{ Lean muscle thickness (mm) } & 63.5 & $60.0 / 69.0$ & 67.0 & $61.5 / 69.0$ & 64.0 & $60.0 / 69.0$ \\
\hline \multicolumn{2}{|c|}{ Fat thickness $(\mathrm{mm})$} & 13.0 & $12.0 / 14.0$ & 15.0 & $14.0 / 15.5$ & 14.0 & $12.0 / 16.0$ \\
\hline \multicolumn{2}{|c|}{ Percentage of lean muscle (\%) } & 58.5 & $57.6 / 60.0$ & 57.2 & $56.7 / 58.7$ & 58.1 & $56.6 / 59.1$ \\
\hline \multicolumn{2}{|c|}{ Dry matter $(\%)$} & 25.2 & $24.4 / 25.5$ & 25.0 & $24.6 / 25.3$ & 25.4 & $24.8 / 25.9$ \\
\hline \multicolumn{2}{|l|}{ Fat $(\%)$} & 2.4 & $1.2 / 2.6$ & 1.9 & $1.7 / 2.1$ & 2.1 & $1.5 / 2.8$ \\
\hline \multicolumn{2}{|c|}{ Collagen (\%) } & 0.5 & $0.4 / 0.6$ & 0.3 & $0.2 / 0.5$ & 0.5 & $0.3 / 0.5$ \\
\hline \multicolumn{2}{|c|}{ Pure protein $(\%)$} & 19.0 & $18.8 / 20.0$ & 19.5 & 19.6/19.6 & 19.9 & $19.4 / 20.4$ \\
\hline \multicolumn{2}{|c|}{ TBA-RS $\left(\mathrm{mg} \cdot \mathrm{kg}^{-1}\right)$} & 1.3 & $1.1 / 1.3$ & 1.1 & $1.0 / 1.2$ & 1.2 & 1.1/1.4 \\
\hline \multicolumn{2}{|c|}{ Drip loss (\%) } & 2.5 & $1.8 / 2.9$ & 2.6 & $2.2 / 3.3$ & 2.4 & $1.8 / 2.7$ \\
\hline \multicolumn{2}{|c|}{ TPA shear force $(\mathrm{N})$} & 64.9 & $58.9 / 72.0$ & 64.4 & $53.6 / 77.6$ & 62.7 & $59.6 / 70.7$ \\
\hline \multicolumn{2}{|c|}{ Cohesiveness } & 1.3 & $1.3 / 1.3$ & 1.3 & $1.3 / 1.3$ & 1.3 & $1.3 / 1.31$ \\
\hline \multicolumn{2}{|c|}{ Cooking loss $(\%)$} & 36.8 & $35.6 / 37.6$ & 37.9 & $36.7 / 38.2$ & 37.5 & $36.3 / 38.0$ \\
\hline & 0 & 6.0 & $5.6 / 6.2$ & 6.0 & $5.8 / 6.2$ & 6.0 & $5.6 / 6.3$ \\
\hline & 24 & 5.5 & $5.5 / 5.6$ & 5.6 & $5.5 / 5.6$ & 5.6 & $5.5 / 5.6$ \\
\hline & 48 & 5.6 & $5.5 / 5.6$ & 5.6 & $5.6 / 5.6$ & 5.6 & $5.5 / 5.7$ \\
\hline & 0 & 39.1 & $39.0 / 40.3$ & 39.4 & $36.2 / 41.2$ & 38.6 & $36.7 / 40.5$ \\
\hline \multirow{3}{*}{$\mathrm{L}$} & 24 & 45.7 & $41.8 / 46.2$ & 45.1 & $43.4 / 46.5$ & 43.3 & $42.0 / 45.8$ \\
\hline & 48 & 43.3 & $42.2 / 46.5$ & 43.6 & $42.4 / 46.4$ & 42.6 & $41.7 / 47.4$ \\
\hline & 0 & 2.2 & $1.3 / 3.5$ & 1.9 & $1.2 / 3.6$ & 2.2 & $0.8 / 2.9$ \\
\hline \multirow[t]{3}{*}{$\mathrm{a}$} & 24 & 2.8 & $2.4 / 4.6$ & 3.2 & $3.0 / 4.2$ & 4.0 & $2.4 / 5.1$ \\
\hline & 48 & 5.6 & $3.9 / 6.4$ & 4.0 & $3.6 / 4.9$ & 5.2 & $4.4 / 6.6$ \\
\hline & 0 & 7.6 & $6.8 / 8.5$ & 6.4 & $5.7 / 8.1$ & 6.6 & $6.2 / 7.3$ \\
\hline \multirow[t]{2}{*}{$\mathrm{b}$} & 24 & 9.2 & $8.4 / 10.0$ & 9.4 & $8.4 / 10.5$ & 9.5 & $8.8 / 10.3$ \\
\hline & 48 & 11.2 & $9.2 / 11.6$ & 10.2 & $8.6 / 11.5$ & 11.3 & $9.6 / 11.6$ \\
\hline \multirow[t]{3}{*}{$\mathrm{C}$} & 0 & 7.9 & $6.9 / 9.0$ & 7.0 & $6.0 / 9.4$ & 7.1 & $6.5 / 7.9$ \\
\hline & 24 & 9.6 & $8.8 / 10.5$ & 10.1 & $8.8 / 11.1$ & 10.1 & $9.4 / 11.0$ \\
\hline & 48 & 12.5 & $10.0 / 13.4$ & 11.3 & $9.3 / 12.5$ & 12.4 & $10.9 / 13.3$ \\
\hline \multirow[t]{3}{*}{$\mathrm{h}$} & 0 & 71.0 & $65.8 / 78.9$ & 74.4 & $66.5 / 82.3$ & 73.7 & $64.7 / 83.7$ \\
\hline & 24 & 72.9 & $66.0 / 74.2$ & 69.8 & $67.4 / 71.9$ & 68.2 & $61.3 / 73.6$ \\
\hline & 48 & 64.3 & $62.8 / 67.5$ & 67.1 & $65.6 / 67.3$ & 63.1 & $58.9 / 66.4$ \\
\hline
\end{tabular}

TBA-RS - Thiobarbituric acid reactive substances, TPA - Texture profile analysis, L - lightness, a - redness, b yellowness, $\mathrm{C}$ - chroma, $\mathrm{h}$ - color hue 
(group A) resulted in higher iodine concentrations compared to the control group. The addition of iodine in the inorganic form (Group B) resulted in significantly $(P<0.05)$ higher concentrations in the thyroid gland tissue compared to the control group. However, there were no differences among groups A and B (Fig. 3).

The indices of carcass characteristics and meat quality traits are presented in Tables 3 and 4. No differences in major carcass measurements (hot weight, lean muscle thickness, fat thickness, muscling) were found during the study. Colour characteristics $\left(\mathrm{L}^{*}, \mathrm{a}^{*}, \mathrm{~b}^{*}\right.$, $\left.\mathrm{C}^{*}, \mathrm{~h}^{0}\right), \mathrm{pH}$ value and lipid oxidation (TBA-RS value) did not differ among the experimental groups. There were no significant differences in cooking loss and drip loss, either.

\section{Discussion}

The minimal dietary iodine requirements for fattening pigs vary according to different scientific committees. Flachowsky et al. (2006) recommend $0.15 \mathrm{mg} / \mathrm{kg}$ dry matter (DM), similarly, NRC (1998) recommend $0.14 \mathrm{mg} / \mathrm{kg}$ DM. According to Schöne et al. (1999), a dose of more than $0.125 \mathrm{mg} / \mathrm{kg} \mathrm{DM}$ is sufficient to sustain normal T4 serum concentrations. The European regulations allow the maximal iodine content of $10 \mathrm{mg} / \mathrm{kg}$ feed (EU 2005). In our experiment we decided to use less than the maximum dose allowed for the following reasons. Firstly, in practice the dose of 1 to $2 \mathrm{mg} \mathrm{I} / \mathrm{kg} \mathrm{DM}$ is used on average (Flachow sky 2007). Secondly, doses over $2 \mathrm{mg} \mathrm{I} / \mathrm{kg}$ diet may cause inhibition of the thyroid hormone formation (Markou et al. 2001). In fact, Schöne et al. (1999) found that the upper limit dose of $10 \mathrm{mg} \mathrm{I} / \mathrm{kg}$ feed doubles the thyroid weight and therefore should be diminished.

In our trial we found significantly $(P<0.05)$ higher iodine concentrations in serum in group A. This fact indicates higher bioavailability of algal iodine compared to group B supplemented with KI. Good bioavailability of iodine from Chlorella spp. was reported also in lactating sows by Kotrbáček et al. (2004). Its use resulted in a higher colostrum iodine content. We have not found any other examples of use of iodine-enriched Chlorella spp. in the literature.

However, iodine concentrations in muscle did not differ between groups A and B. Experiments with marine algae indicate that the iodine tissue concentrations differ among various algal species. He et al. (2002) found that the iodine concentrations in muscle achieved by iodine from the marine alga Laminaria digitata were superior to inorganic iodine when used in growing-finishing pigs. On the contrary, lower bioavailability of iodine from the alga Eucheuma spinosum was determined by Kaufmann et al. (1998) in laying hens. These differences are probably caused by different compositions of iodine compounds in algal species (El-Naggar 1995). Hou et al. (1997) found that the marine alga Laminaria digitata contains high percentage of inorganic iodine (up to $90 \%$ ). Only about $10 \%$ of iodine consists of organic iodine in the form of iodo-amino acids. On the other hand, the leachate of Laminaria japonica contains $51 \%$ of organic iodine (Wang 1995). The iodine speciation profile of iodine-enriched Chlorella spp. is not yet known. Higher iodine serum concentrations of iodine from Chlorella spp. indicate that a major part of iodine is present in the organic form. As algal biomass of iodine-enriched Chlorella spp. was used in our study, it is also possible that a proportion of organic iodine in algal biomass is higher than in intact algal cells.

The finding that algal iodine did not produce higher iodine concentration in the muscle tissue in group A could be possibly attributed to the fact that very small iodine concentrations are retained in the muscle tissue. Compared to the thyroid, very small iodine concentrations are present in muscle and fat tissue of both pig groups. According to Franke et al. (2008) the thyroid contains $80 \%$ of body's iodine, innards/blood $14 \%$, muscle/fat $5 \%$ and bones 
$1 \%$. The average iodine concentration in the meat of group A was $18.5 \mu \mathrm{g} \mathrm{I} / \mathrm{kg}$ fresh matter. In group B the average iodine content in muscle $(11.5 \mu \mathrm{g} \mathrm{I} / \mathrm{kg}$ fresh matter) was not significantly higher. The WHO scientific committee (2002) recommends $150 \mu \mathrm{g}$ iodine per day for adults. Based on the average annual consumption of pork in the Czech Republic $(50 \mathrm{~kg})$ and on the average iodine content in meat, we have calculated that pork from group A would provide $2 \%$ and pork from the group B $2 \%$ of the iodine requirement in humans per year. Our results are similar to D-A-CH (2000) and Herzig et al. (2005) who found that pork could just contribute about $1 \%$ or $1-2 \%$ to the recommended iodine intake. The uninfluenced growth performance in the group without iodine supplementation could be attributed to the fact that the iodine content in the basal diet met the existing references for fattening pigs. No differences in meat quality traits were observed between the two groups. Thyroid hormones affect the growth of adipocytes and their differentiation (Ailhaud et al. 1992). As indicated by uninfluenced fat thickness and meat texture (marbling score), the iodine content in the non-supplemented group $\mathrm{C}$ was able to sustain a normal homeostasis of fat depots. The use of a high dietary dose of iodine in our trial did not affect negatively the meat quality. This is in agreement with the findings of Meyer et al. (2008) and He et al. (2002). Kaufmann et al. (1998) found no differences in the meat quality traits although a very high iodine level of $30 \mathrm{mg} / \mathrm{kg}$ feed was used in the diet.

In conclusion, iodine from iodine-enriched Chlorella spp. is retained in the muscle tissue at concentrations that are comparable to inorganic KI. Even when high iodine concentrations are used in the diet, the iodine content in muscle is still very low to be considered as a relevant iodine source for human nutrition. Our explanation of similar concentrations in the muscle tissue in both groups (A and B) of pigs is that the freshwater alga Chlorella spp. probably contains high percentage of inorganic iodine. Hou et al. (1997) found that the marine alga Laminaria digitata contains a high percentage of inorganic iodine (up to $90 \%$ ).

\section{Acknowledgements}

The study was supported by Ministry of Education, Youth and Sports of the Czech Republic (MSM Project No. 6215712403).

\section{References}

Ailhaud G, Grimald P, Negrel R. 1992: Cellular and molecular aspects of adipose tissue development. Annu Rev Nutr 12: 207-233

D-A-CH- 2000: Deutsche Gesellschaft für Ernährung (DGE), Österreichische Gesellschaft für Ernährung (ÖGE), Schweizerische Gesellschaft für Ernährung (SGE), Schweizerische Vereinigung für Ernährung (SVE) Referenzwerte für die Nährstoffzufuhr: Jod. (German, Austrian and Swiss nutrition standards) Umschau Braus Verlag, Frankfurt am Main, 1. Auflage.179-184

Delange F 1994: The disorders induced by iodine deficiency. Thyroid 4: 107-128

El-Naggar MEE 1995: Distribution of iodine in Egyptian marine algae. Mar Sci 6: 151-160

EU 2005: Verordnung (EG) Nr. 1459/2005 der Kommission zur Änderung der Bedingungen für die Zulassung der Spurenelemente. Amtsblatt der Europäischen Union, L 233/8-10

Flachowsky G 2006: Proceedings of the Society of Nutrition Physiology. J Anim Physiol An N 90: 354

Flachowsky G 2007: Iodine in animal nutrition and iodine transfer from feed into food of animal origin. Institute of Animal Nutrition, Federal Agricultural Research Centre (FAL), Braunschweig, Germany 42: 47

Flachowsky G, Schöne F, Jahreis G 2006: Iodine enrichment of food of animal origin (in German). Ernäh Umsch 53: $17-21$

Franke K, Schöne F, Berk A, Leiterer M, Flachowsky G 2008: Influence of dietary iodine on the iodine content in pork and the distribution of the trace element in the body. Eur J Nutr 47: 40-46

He ML, Hollwich W, Rambeck WA 2002: Supplementation of algae to the diet of pigs: a new possibility to improve the iodine content in meat. J Anim Physiol An N 86: 97-104

Herzig I, Trávníček J, Kursa J, Kroupová V. 2005: The content of iodine in pork. Vet Med - Czech 50: 521-525

Herzig I, Trávníček J, Kursa V, Kroupová J, Rezníček I 2007: Content of iodine in broiler meat. Acta Vet Brno 76: $137-141$

Hou X, Chai C, Qian Q, Yan X, Fan X 1997: Determination of chemical species of iodine in some seaweeds. Sci Total Environ 204: 215-221 
Kaufmann S, Rambeck WA 1998: Iodine supplementation in chicken, pig and cow feed. J Anim Physiol Anim Nutr 80: 147-152

Kaufmann S, Wolfram G, Delange F, Rambeck WA 1998: Iodine supplementation of laying hen feed: a supplementary measure to eliminate iodine deficiency in humans? Z Ernahrungswiss 37: 288-293

Kotrbáček V, Doucha J, Offenbartl T 2004: Use of chlorella as a carrier of organic-bound iodine in the nutrition of sows. Czech J Anim Sci 49: 28-32

Kotwal A, Priya R, Quadeer I 2007: Goiter and other iodine deficiency disorders: a systematic review of epidemiological studies to deconstruct the complex web. Arch Med Res 38: 1-14

Lauerberg P 2004: Victories and challenges in optimizing iodine intake. Thyroid 14: 589

Markou K, Georgopoulos N, Kyriazopoulou V, Vagenakis AG. 2001: Iodine induced hypothyroidism. Thyroid 11: $501-510$

Meneton P, Jeunemaitre X, De Wardener HE, MacGregor GA 2005: Links between dietary salt intake, renal salt handling, blood pressure, and cardiovascular diseases. Physiol Rev 85: 679-715

Meyer U, Weigel K, Schöne F, Leiterer M, Flachowsky G 2008: Effect of dietary iodine on growth and iodine status of growing fattening bulls. Livest Sci 115: 219-225

Niedobová E, Machát J, Otruba V, Kanický V 2005: Vapour generation inductively coupled plasma optical emission spectrometry in determination of total iodine in milk. J Anal At Spectrom 20: 945-949

NRC 1998: Nutrient Requirements of Swine. 10th Ed. Nat. Acad. Press, Washington, D.C., pp. 53-54

Schöne F 1999: Iodine deficiency, iodine requirement and iodine excess in farm animals - Experiments in growing pigs. Berl Munch Tierarztl 112: 64-70

Schöne F, Lebzien P, Bemmann D, Leiterer M, Spolders M, Flachowsky G. 2006: Influence of increasing dietary iodine supplementation of feed on iodine concentration in blood serum and milk of dairy cows. Proc Soc Nutr Physiol 15: 172

Wang XA. 1995: Study of the content, distribution and chemical species of Laminaria japonica (in Chinese). M. Sc. Thesis, Institute of Oceanology, Academia Sinica, Qingda, China

WHO (World Health Organisation) 2002: Opinion of the scientific committee on food on the tolerable upper intake level of iodine. SCF/CS/NUT/UPPLEV/26 Final; 1-25

Zamrazil V, Čeřovská J, Dvořáková M. 1996: Iodine deficiency in Czech Republic. In: Neve J, et al. (eds.). Therapeutic uses of trace elements. Plenum Press, New York, London: 329-332

Zamrazil V, Čeřovská J, Bílek R, Dvořáková M, Němeček J, Vavřejnová V, Zamrazilová H. 2007: Evaluation of results of iodine prophylaxis in Czech Republic. Časopis českých lékařŭ 146: 262-266 